\title{
Defying Maintenance Mimesis: The Case of Somewhere over the Balcony by Charabanc Theatre Company
}

Making reference to Luce Irigaray's definitions of mimesis and mimicry, and the ways in which these concepts respectively reinforce and challenge the phallogocentric order, this article investigates the representation of the Troubles in the play Somewhere over the Balcony by Charabanc - a pioneering all-female theatre company which operated in Belfast in the 1980s and early 1990s. The article discusses the achievement of the company in the local context and offers a reading of Somewhere over the Balcony, Charabanc's 1987 play which depicts the lives of underprivileged working-class Catholic women in the infamous Divis Flats in Belfast. Showing the protagonists' struggle with the everyday reality of sectarianism in Northern Ireland, it celebrates female creativity and jouissance. The article argues that the characters challenge the masculinist order by means of mimicry. Irigaray defines this strategy as a deliberate assumption of prescribed female roles, which involves a playful attitude to "mimesis imposed"-in other words, to the programmed repetition of socially sanctioned patterns (This Sex 76). Mimicry, as well as other productive strategies help the female characters in the play to transform the balconies of their flats into an area of creativity and empowerment, which challenges binary thinking about the division into private and public space. Such a geopolitical reading of the play corresponds to the artistic agenda of the company, communicated by its very name. It also sheds light on Charabanc's attempt to create a more inclusive and varied cultural space that would reach beyond gender, sectarian, and class divides in Northern Ireland.

Keywords: Northern Irish drama, Charabanc, Luce Irigaray, mimicry, mimesis, Somewhere over the Balcony. 
The founding of the all-female Charabanc theatre company in 1983 can be seen as a breakthrough for women in Northern Irish theatre. Three years earlier, in 1980, another influential theatre company, Field Day, was established by two prominent figures in Irish culture: dramatist Brian Friel and actor Stephen Rea. Apart from the contribution they made to Irish theatre, one of the company's major achievements was the publication of a comprehensive anthology of Irish writing which, as its editor, Seamus Deane, explains in his introduction, sought to envisage "the forces and ideas that have governed the development of the always putative subject 'Irish writing' over 1,500 years" ( $\mathrm{xx}$ ). The scope of the project was unprecedented, as this was the first attempt to systematize Irish writing from a historical perspective in such a thorough way. It is no wonder that once the anthology saw the light of day, the choice of the texts selected and left out generated a heated debate. One of the major accusations that Field Day faced concerned the gross underrepresentation of Irish female writers in the three volumes. The unfortunate "oversight" was soon amended. In 2002, volumes four and five of the anthology, dedicated exclusively to female writers, historians, theologians, journalists, political activists, and the like were released in print. Although this does some justice to the women whose voices were silenced in 1990, their texts were not incorporated into the all-male anthology but were collected in separate volumes, which somewhat reinforced the male/female binary rather than creating a more inclusive forum for literary expression that would go beyond gender polarity. The rigid division, reflecting the sharp male/ female dichotomy visible in Northern Irish society, was playfully explored by Charabanc in a number of their plays. As my analysis of Somewhere over the Balcony will show, their dramatic texts often achieve this aim by the conscious use of mimicry rather than adherence to the conventions of "maintenance mimesis" (Robinson 27) which Luce Irigaray defines as automatic, repetitive copying of the male standards that have dominated female expression in patriarchal, Western societies (This Sex 131).

The exclusion of women from the canon of Irish literature by Field Day mirrored the situation in Northern Irish theatre in the early 1980s, where female actors stood little chance of professional success. Charabanc was founded by five Irish actresses: Marie Jones, Carol Scalan, Eleanor Methven, Maureen Macauley, and Brenda Winter, distressed by the lack of opportunities for professional development in Belfast. As Methven explains,

When we weren't unemployed, the work we got wasn't good quality-the wife, the mother, the usual sort of roles actresses get, or the background for some guy on stage. So the company was born out of frustration and boredom and the desire to do good work. (qtd. in Martin 89-90) 
Although there are similarities between the two companies, in certain respects Charabanc defined themselves in opposition to the mainstream Field Day. ${ }^{1}$ The main difference consisted in the fact that their plays adopted a working-class, female perspective on the Northern Irish present and past.

Interestingly, Charabanc was not even intended to be an all-female ensemble, and it was purely economic circumstances that determined the composition of the company. As DiCenzo remarks,

They [Charabanc] were on a social welfare scheme designed to deal with long-term unemployment, whereby the government paid eighty percent for their wages for the year, based on the Equity minimum. But to qualify for the scheme one had to have been unemployed for a certain number of months and even though Charabanc had created parts for men in the play [Lay Up your Ends], they could not find any actors who had been out of work for that long. (179)

Despite the fact that the female perspective is one of the hallmarks of Charabanc, its members were reluctant to label the company "feminist." As Marie Jones explains, this would significantly weaken their social agenda. She states:

At the time when Charabanc started . . . there were a lot of English theatre companies, trendy, middle-class and presenting feminism, and calling themselves feminist. It could be alienating and we were trying to encourage people to go to the theatre, people who had never been before, and we didn't want to put them off by having any kinds of labels, we just wanted to say that this is a play about ordinary people. (qtd. in Foley 30)

Carefully avoiding sectarian or gender polarities, Charabanc preferred to define themselves along the lines of social class as a working-class theatre company, deeply rooted in the working-class theatre aesthetics. Most of their early plays are characterized by the nine elements playwright and theatre theorist John McGrath considered as typical of working-class theatre: the direct treatment of the problem, sharp comedy, the use of music, openness to emotion on the stage, elements of variety entertainment, "a moment-bymoment effect" (rather than "a slow build-up to great dramatic moments"), immediacy, strong localism, and the audience's sense of identity with the performer (54-61). The members of Charabanc did not position themselves

1 An interesting comparison between Field Day and Charabanc can be found in Lojek. 
against the working-class theatre tradition broadly defined by McGrath, but claimed a legitimate part in it and pushed its boundaries to include the marginalized female perspective and the company's novel aesthetics.

One of the means to achieve this aim was to reconsider the production process. As DiCenzo puts it, Charabanc was a "theatre that has not conformed - and does not wish to conform-to an intellectual and organisational establishment" (184). Even though Marie Jones played a major role as the company's playwright, their productions frequently involved collective research into a given topic and a considerable amount of devising strategies, while the further creative process "reverse[d] the traditional writer/director dominated power structure" (Martin 89), since directors for their performances were commissioned by the actresses themselves.

The name of the company derives from the tradition of working-class women from Belfast who would occasionally hire a charabanc, a holiday bus, and together go on a tour outside the city (Methven and Moore 278). Such a form of entertainment gave them a temporary relief from daily chores and helped them distance themselves from everyday problems. This new, female, working-class perspective on everyday life in Northern Ireland became the hallmark of Charabanc's productions. Endowed with a large dose of carnivalesque humour, such a distanced approach can, for instance, be found in Charabanc's 1987 play Somewhere over the Balcony, written by Marie Jones in collaboration with other members of the company and lauded by Claudia W. Harris as "the creative culmination of the best qualities of Charabanc's early work" (xliii). Taking its audience on an engaging tour of one of the deprived areas of the Northern Irish capital, the play focuses on the lives of three Catholic women: the industrious widow Ceely Cash, who runs a souvenir shop with military equipment found in the streets of Belfast and who unites the local female community sharing local news and running bingo games via her illegal pirate radio station; pious Kate Tidy, who lives in her dilapidating flat with her son, a dog, and a collection of saint figurines; and Rose Marie Noble, an overprotective mother of twins.

The protagonists live in the infamous Divis Flats in Belfast. Built in the 1960s in the Falls neighbourhood, which has been the centre of Republican activity, and mostly demolished by the end of the 1980s, Divis Flats came to be known as a Catholic ghetto which provided very poor housing conditions. Surrounded by poverty and the raging sectarian conflict, the women perform the traditional roles of caring mothers and homemakers. At the same time, the female microsociety they create on the balconies of their flats helps them perform these roles consciously with a large dose of mockery and irony, and thus, manifest their resistance to the dominant patriarchal stereotypes of femininity. 
In order to explain the subversive strategies used by the protagonists of the play, it is useful to explore Luce Irigaray's concept of mimesis, which is based on the distinction between the two forms of mimesis postulated by Plato. Irigaray explains that "there is the mimesis that would be already caught up in a process of imitation, specularization, adequation, and reproduction" (This Sex 131). It is an imitation of an imitation, which only increases the distance from the true nature of things. The other repressed form of mimesis is associated with production, rather than reproduction. “[C] onstituted as an enclave within a 'dominant' discourse" (Irigaray, This Sex 131), it is envisaged as a source of female creativity. Irigaray associates productive mimesis with the domain of music. Ladelle McWhorter aptly explains its nature by making a comparison to a performance of a musical score, which "is never adequation or mere reproduction; it is always open to difference," and to the music of a mockingbird (161). This suggests that productive mimesis always involves a departure from a given model, which reveals the artificial construction and performative character of this model. One way to achieve such an aim is to take recourse to Irigaray's concept of mimicry, a playful imitation which challenges the meaning, nature, and significance of the original model. Involving a playful attitude to maintenance mimesis, its goal is to denaturalize and bring to light "what was supposed to remain invisible" (This Sex 76) and is just a fake construct. In its strife to articulate what is not supposed to be exposed, mimicry not only reveals the social performativity of gender roles, but can give voice to female pleasure as well. This highlights the subversive nature of such a strategy since, as Irigaray notes, "what is most strictly forbidden to women today is that they should attempt to express their own pleasure" (This Sex 77). Mimicry, as an instance of productive mimesis, is the opposite of assimilation and docility. It involves constant tension with the "mimesis imposed" (Irigaray, Speculum 59-61). It also facilitates the development of a processual identity which avoids fixity and is based on constant reinventing and pushing the boundaries of female gender roles. As will be shown, the protagonists of Somewhere over the Balcony have mastered various productive mimetic strategies which help them challenge gender, as well as sectarian divisions antagonizing Northern Irish society.

As its title suggests, the play is set on the balconies of Divis Flats, a location whose symbolic and social significance in the play corresponds to the key ideas implicit in the name of the company. Historically speaking, going on a charabanc tour entailed a crucial change of perspective and created a distancing effect. It was a form of entertainment which allowed working-class women to temporarily resign from their role as participants in everyday life and become more objective observers. It created a sense of distance and detachment which is necessary to interpret and mimic the 
whole reproductive "economy of representation" (Irigaray, This Sex 152). The same is true for the protagonists of the play under discussion, who eagerly escape the narrow domestic space whose vulnerable walls literally fall apart under the pressures of the sectarian conflict raging around it. When Mary Rose is arrested and taken away for interrogation under the suspicion of being involved in Republican terrorism, Ceely comments: "She'll love it. Isn't it getting her out of the house for a couple of hours?" (Jones 202). Similarly, Kate revels in her moments of peace and quiet while emptying her dustbin in the morning and thus stubbornly resists the idea of using the rubbish chute.

Islanded among raging chaos, the protagonists of the play spend most of their free time on the balconies-in a no man's land between the two warring factions, the British military forces stationed at the top of the nearby Divis Tower and a group of Irish Republicans wreaking havoc in the streets. They are presented as witnesses of the absurd sectarian spectacle taking place in front of their eyes, and their engagement in these manic events can often be seen as similar to that of an audience commenting on a sporting match. Like Claudia W. Harris, one could also compare the women to "a surreal Greek chorus" (xliv), or to theatre spectators.

In fact, the balconies serve as a metatheatrical device which facilitates a reversal of the critical gaze of the audience. The events described by the protagonists happen just outside the flats, as if in the auditorium, which accentuates the engagement of the spectators in the absurdities of sectarianism. Most importantly, though, the specific location of the play reinforces the distanced attitude of the characters to the surrounding chaos and violence, on which they comment with a large dose of humour and irony. Examining the way of experiencing the world below by a person standing at the top of the World Trade Centre, Michel de Certeau writes:

Elevation transfigures him into a voyeur. It puts him at a distance. It transforms the bewitching world by which one was "possessed" into a text that lies before one's eyes. It allows one to read it, to be a solar Eye, looking down like a god. (92)

A similar sense of empowerment deriving from the change of perspective can be found in Somewhere over the Balcony. Yet the balconies of Divis Flats are not only a site of observation, interpretation and commentary, but also of intervention. The women do not hesitate to interfere in the mad spectacle taking place outside when its participants fail to perform their roles properly, as in the case of the priest who orders the people barricaded in the nearby chapel to surrender to the British military forces and is immediately silenced by the protagonists, who hit him, using a toy catapult. 
At times, the balcony gives the protagonists a possibility to influence the absurdly chaotic reality that surrounds them. Yet most often it serves as a site where they exercise imaginary control, which accentuates the parodic aspect of their performance. Seeing a British army chopper landing on the top of the nearby Divis Tower, "KATE and ROSE pretend to bring [it] down to land" (Jones 184). This gesture is an example of what may be called "counter-mimicry"-a deliberate, theatricalized performance of the opposite role to that expected of a woman (an underprivileged Northern Irish Catholic and a working-class member), which exposes the protagonists' powerlessness. Although Ceely, Kate and Rose often attempt to bring some order to the world around them, the commands that they shout at their husbands, children and dogs are rarely heard or followed.

As in the times of the Troubles, the women presented in the play are still bound to play supporting roles in their men's struggle against British invaders. Yet, again, to use Irigaray's words, they do "not will to be their [men's] equal[s]" (This Sex 152), but use their exclusion and marginality as an asset which facilitates productive mimesis. During the Troubles, one of the roles given to women consisted in keeping a look-out and warning men against the approaching British forces by banging bin lids. Comically distorted, the legacy of the Troubles is still alive in the play. The women keep a look-out in order to warn their unemployed husbands against "dole snoopers," which is but another instance of mimicry effectively replacing sectarian pathos with subversive bathos.

Furthermore, in Somewhere over the Balcony the perspective according to which the role traditionally attributed to Northern Irish women was to support their partners in their sectarian strife is reversed-the so-far nameless helpers are individualized and brought to the fore, while the men constitute a rather homogenous background for their actions. Most of them are named Tucker ("a pet name for Thomas"), "according to Marie Jones, used consistently in the text to suggest the alliterative effect of the constant tuc tuc tuc of overhead British Army surveillance helicopters" (Foley 43). The application of this common "generic" name suggests entrapment in the narrow confines of Irish masculinity. Male sectarianism is further ridiculed by the protagonists, who perceive their husbands as lazy idlers. Therefore, the women grant the status of local heroes not so much to their men, but to their dogs whose deeds they commemorate in a song performed to a traditional Irish shanty tune, "The Holy Ground": 2

2 In general, the sense of joy and playfulness permeating the female community is particularly conspicuous when the characters sing their songs, in a Brechtian fashion commenting on the problems they experience in their everyday lives. 
Oh, Rambo McGlinchey, you've only got one eye.

You're fearless and brave, and for us you would die.

You take on the British with no weapons at all,

And when Ireland at last is free you will hang on our wall. (Jones 186)

A curious and grotesque mixture of popular culture and Irish Republicanism, the one-eyed poodle who "ate more soldiers' legs than dog biscuits" (Jones 186) combines the features of the protagonist of the American action film series and the head of the illegal Irish National Liberation Army and thus ridicules the local die-hard nationalism and maledominated sectarianism as a whole. The song also suggests the inadequate nature of the male role models which in real life are never fulfilled.

In general, apart from the occasional moments of threat and menace, when gathered on their balconies, the protagonists seem to enjoy watching the havoc on the ground. They act as mockingbirds, presenting the audience with an image of the sectarian conflict which resembles a comedy of errors and a lively masquerade. Thus, the balconies can be perceived as a stronghold of the women's creative and expressive power, as they offer a convenient perspective to examine sectarianism, the working-class ethos, and conventional gender roles in a playful manner, revealing their performative nature.

Traditionally, a balcony often reflected the marginal role of women in public life. ${ }^{3}$ It has frequently been defined as a female space, a substitute for a garden and an extension of the domestic sphere, indicating a sense of entrapment within narrowly-defined gender roles. At the same time, a balcony may be seen as a liminal space-a borderland between maledominated, public and stereotypically female, private space. Suspended between these two gendered areas, it serves as a perfect "outside" or "third" space (to borrow the phrase from Homi Bhabha ${ }^{4}$ ) where mimicry and counter-mimicry can be practised. In Charabanc's play the balcony is envisioned as a carnivalesque space of female laughter, pleasure, and subversion. This is where the protagonists create their own community, which to some extent fits into Julia Kristeva's definition of

3 An interesting example taken from a different cultural context is the ballroom of the National Press Club in Washington, where the state authorities frequently gave their addresses. Since women were not allowed inside, female reporters had to cover these speeches from a balcony above the ballroom.

4 Bhabha explains the concept of the "third space" in the book The Location of Culture, where he states that it is "the cutting edge of translation and negotiation, the in-between space-that carries the burden of the meaning of culture" (38) and adds that "by exploring this Third Space, we may elude the politics of polarity and emerge as the others of our selves" (39). 
"countersociety"- “a sort of an alter-ego of the official society, in which real or fantasized possibilities for jouissance take refuge [and which is] imagined as harmonious, without prohibitions, free and fulfilling” (870). Still, as Kristeva further asserts, countersociety "generates ... its essence as a simulacrum of the combated society or of power" (871). By employing productive solutions, the female community presented in the play does not fall into the trap of simulacra, i.e. the trap of maintenance mimesis. As Robinson notes, "in productive mimesis ... the aim is to develop, add to or exceed a given situation that has been found insufficient to allow for the articulation of subjectivity" (39-40). I believe that one of the ways in which this concept may be realized is through creative recycling.

For instance, this process is visible when the female characters appropriate objects belonging to the male world to their advantage. One example of such a strategy is the recycling of sectarian war paraphernalia. Like Mother Courage from Bertolt Brecht's famous play, the women feed on war, trying to transform its downsides into a source of material profit which will improve the poor financial situation of their families. By doing so, they also participate in the local economy. They enjoy this privilege, yet approach it with a large grain of mockery targeted at so-called "Troubles tourism." Kate, for instance, attempts to sell a bin lid as a souvenir to a German journalist for two hundred pounds, claiming that it is "the first bin lid ever banged on internment morning" (Jones 188). ${ }^{5}$ The industrious Ceely opens her own small souvenir shop with rubber bullets, riot gear, and gas masks gathered in the streets of Belfast. In a sense, this idea of re-appropriation and re-exploration of the objects belonging to the male-dominated sphere corresponds to what Charabanc strived to achieve when they entered the Northern Irish stage and adapted it to the new perspective they offered.

A crucial element that reinforces the bonds in the female alternative society depicted in the play is the stolen radio transmitter that Ceely uses to run her own local pirate station. In a chatty, conversational manner, she shares the local news and announcements with her neighbours. The radio provides the female community in Divis Flats with bingo gaming and, in the case of trouble, an emergency means of communication. From the male, sectarian perspective, the radio is a "suspect device" (Jones 203) the British security forces want to confiscate from the flats when they ask the inhabitants to leave their homes. For Belfast audiences, the scene would have echoed the tragic story of Jean McConville, an inhabitant of Divis Flats, accused of informing to the British and put to death by the

5 As has been mentioned, during the Troubles, Republican women used to bang their bin lids to warn their neighbourhood about upcoming danger. The role of bin lids in the play has been discussed in detail by Eleanor Owicki (56-66). 
Provisional IRA in 1972. Brendan Hughes, the Officer Commanding of the Belfast Brigade of the IRA, explains the rationale behind the execution in the following way:

I'm not sure how it originally started, how she became ... an informer [but] she was an informer; she had a transmitter in her house.... We received information from — that-had something in the house. I sent ... a squad over to the house to check it out and there was a transmitter in the house. We retrieved the transmitter, arrested her, took her away, interrogated her, and she told [us] what she was doing. We actually knew what she was doing because we had the transmitter. . . And because she was a woman ... we let her go with a warning [and] confiscated the transmitter. A few weeks later, I'm not sure again how the information came about ... another transmitter was put into her house ... she was still co-operating with the British. (qtd. in Moloney 128-29)

This story reinforces the idea of a radio transmitter as a "suspect device," largely associated with male-dominated, public space and the sectarian conflict. In spite of the possible danger connected with using such a device in Divis Flats, Ceely's radio has been transformed into a tool for expressing female communal spirit. As in the case of war paraphernalia or the dustbin lid, the women use the device for their own, non-sectarian purpose, which helps them create an alternative social space according to their own agenda.

The perspective offered in the play ridicules the concept of male, public space as a domain of reason. One day in the lives of the denizens of Divis Flats is presented through the eyes of the protagonists in an absurd and exaggerated fashion. The public space surrounding the balcony is a site of chaos and anomie with children and dogs joyriding in an ambulance, wedding guests barricading themselves in a chapel surrounded by the British, exploding cars, hijacked helicopters, and local youngsters burning Union Jacks on the roof of a chapel. As Methven explains, "parameters of normality have stretched so much, that no matter what you put in [the play], you will find a parallel for it in everyday normal life" (qtd. in DiCenzo 181). The drama suggests that in sectarian, conflict-ridden Northern Ireland the notions of rationality and social progress are to be found not so much in the male-dominated, violent and dysfunctional public space but on the fringes of the domestic and the public, on the balcony-a site of productive mimesis and jouissance.

In Charabanc's play, the balcony is where one may both exercise and be subjected to close observation, the latter being facilitated by the opening of an observation post on the top of the nearby 61-meter-tall Divis Tower. As Kate describes it, 
I remember when the British army moved into that Tower block ... my Frank says "Them bastards are watching us." Says me, "They must have bloody good eyesight cos they are fifteen floors up." "Cameras," he says. "Close-up cameras." And lo and behold that very next day there was five soldiers hokin' around in my rubbish ... but I don't care cos I never done nothin' as long as I can't see them looking at me. So I just bought myself a new dressing gown and ignored them. . . "They can hear you too," says he... . "Big deal," says me, "sure them English can't understand us anyway." (Jones 183)

The panoptical character of the surveillance seems to be much more successful in relation to men, such as Granda Tucker, who for twelve years has not left his flat nor spoken a word for fear of being seen or heard by the British. The women, by contrast, attempt to preserve the façade of normality, trying to ignore the oppressors or challenging their power and authority. They do not let themselves be confined within the four walls marking the boundaries of the domestic area, and they defend the communal space they have created for themselves on the balconies, where they are both objects of observation, remaining under the watchful eyes of the British army, and observers subverting the gaze of the British soldiers. They consciously and playfully respond to political surveillance to which they have been exposed by envisioning it as an instance of male gaze and performing a traditional masquerade of femininity. Kate, for instance, in a mocking fashion presents herself as an attractive object of male desire by clothing herself in a new dressing gown and Ceely strikes several provocative, sexy poses for the British voyeurs stationed at the top of the tower (Jones 187). The women from Divis Flats take pleasure in a temporary reversal of gendered models of behaviour. What particularly attracts their attention are soldiers, "all hot and sweaty" (Jones 185), jogging at the top of the tower, about whom they share their erotic fantasies with the audience. In this way, the protagonists reverse the objectifying gaze and direct it at the male surveillant. They mimic the male gaze, playfully reclaiming the right to derive erotic pleasure from the act of gazing at the object of their desire, subverting the vertical hierarchy, and transforming the panoptic system of male surveillance into a female synopticon.

Although the protagonists mostly approach the rigid gender roles that prevail in the local community from a distanced, playful perspective, there are times when desperate to have some control over the raging chaos, they fall into the trap of hysteria. In her analysis of Irigaray's writing, Robinson describes the concept of "hysterical mimicry" as informed by a woman's "wishes to regain and retain her subjectivity through absolute control of that 'femininity,' exceeding it through becoming the 
best at it" (40). Such a strategy is essentially unproductive. Robinson explains that "the mimesis of the hysteric is doomed to be a mimesis of powerlessness, mimicry of a 'femininity' that was never 'hers"' (40). In Somewhere over the Balcony, such an instance of overcompliance can be found when abandoned by her husband, Kate desperately tries to make her flat a decent place to live in for her young son. Her economic situation, however, does not give her any hope for a bright future. In the past blamed by her now absent husband for their daughter's untimely death and every, even minute, misfortune or inconvenience that they had encountered, Kate has turned to religion and assumed the role of a Godfearing Catholic housewife. Having internalized the sense of guilt, she hopes to atone for her sins and be rewarded for her devotion-to break the vicious circle of misfortune. Her excessive religious behaviour does not, however, lead to the desired effect. The walls of her flat eventually crumble down and the ceiling seems to be about to collapse. Kate's strong eagerness to fulfil the given social role of a dutiful wife, caring mother, and devout Catholic only leads to the escalation of self-blame. Most of the time, however, the protagonists of the play avoid overcompliance and replace it with mimicry and counter-mimicry.

To conclude, by effectively using the setting of the play as a site of productive mimesis, which operates outside the traditional male/female, public/private binary systems, Charabanc's Somewhere over the Balcony examines the possible strategies of pushing the narrow boundaries of the social roles that the female protagonists have been made to perform. To use Irigaray's words, the characters "play with mimesis" and bring "new nourishment to its operation" (This Sex 76). Their strategies of resistance against maintenance mimesis include both mimicry, which involves a deliberate assumption of "the feminine style and posture assigned to her by [patriarchal] discourse" (Irigaray, This Sex 220), and what may be called counter-mimicry, which denotes a deliberate assumption of the unfeminine style and posture not so much to embrace them, but to examine them in a playful way and reveal the artificiality of the social constructs to which they belong. In the play, this is possible thanks to the distancing effect of the balconies. They serve as a counterspace which does not simply reproduce the arrangements governing the official space, but rather seeks to creatively expand and transform it by laying bare its constructedness. In this respect, the play offers a metacommentary on Charabanc's own creative practice which sought to expand the scope of voices and perspectives represented in Northern Irish theatre by introducing a new working-class aesthetics and a more collaborative, open and democratic creative process to the Northern Irish theatre tradition. 


\section{Works Cited}

Bhabha, Homi K. The Location of Culture. London: Routledge, 1994. Print.

Deane, Seamus. General Introduction. Field Day Anthology of Irish Writing.

Vol. 1. Ed. Seamus Deane. Derry: Field Day, 1991. xix-xxvi. Print.

Certeau, Michel de. The Practice of Everyday Life. Trans. Steven Rendall. Berkeley: U of California P, 1988. Print.

DiCenzo, Maria R. "Charabanc Theatre Company: Placing Women Center-Stage in Northern Ireland." Theatre Ireland 45.2 (1993): 17484. JSTOR. Web. 16 Apr. 2016.

Foley, Imelda. The Girls in the Big Picture: Gender in Contemporary Ulster Theatre. Belfast: Blackstaff, 2003. Print.

Harris, Claudia W., ed. The Charabanc Company: Four Plays. Gerrards Cross: Smythe, 2006. Print.

Irigaray, Luce. Speculum of the Other Woman. Trans. Gillian G. Gill. Ithaca: Cornell UP, 1985. Print.

---. This Sex which Is Not One. Trans. Catherine Porter and Carolyn Burke. Ithaca: Cornell UP, 1985. Print.

Jones, Marie. "Somewhere over the Balcony." The Charabanc Company: Four Plays. Ed. Claudia W. Harris. Gerrards Cross: Smythe, 2006. 181-224. Print.

Kristeva, Julia. "Women's Time (1981)." Feminism: An Anthology of Literary Theory and Criticism. Ed. Robyn R. Warhol and Diane Prince Herndl. New Brunswick: Rutgers, 1997. 855-79. Print.

Lojek, Helen. "Playing Politics with Belfast's Charabanc Theatre Company." Politics and Performance. Ed. John P. Harrington and Elizabeth J. Mitchell. Amherst: U of Massachusetts P, 1999. 82-102. Print.

Martin, Carol. “Charabanc Theatre Company: 'Quare' Women 'Sleggin' and 'Geggin' the Standards of Northern Ireland by 'Tappin' the People." TDR: The Drama Review 31.2 (1987): 89-99. JSTOR. Web. 16 Apr. 2016.

McGrath, John. A Good Night Out: Popular Theatre: Audience, Class and Form. London: Methuen, 1982. Print.

McWhorter, Ladelle. "The Private Life of Birds: From a Restrictive to a General Economy of Reason.” Reading Bataille Now. Ed. Shannon Winnubust. Bloomington: Indiana UP, 2007. 141-65. Print.

Methven, Eleanor, and Carol Moore. "Charabanc Theatre Company on Irish Women's Theatres." Feminist Stages: Interviews with Women in Contemporary British Theatre. Ed. Lizabeth Goodman and Jane de Gay. Amsterdam: Harwood, 1996. 278-82. Print.

Moloney, Ed. Voices from the Grave: Two Men's War in Ireland. New York: Public Affairs, 2010. Print. 
Owicki, Eleonor. "Rattle Away at Your Bin: Women, Community, and Bin Lids in Northern Irish Drama." Theatre Symposium. The Prop's The Thing: Stage Properties Reconsidered 18 (2010): 56-66. Project MUSE. Web. 16 Apr. 2016.

Robinson, Hilary. Reading Art, Reading Irigaray: The Politics of Art by Women. London: Tauris, 2006. Print.

Katarzyna Ojrzyńska is Assistant Professor in the Department of Studies in Drama and Pre-1800 English Literature at the University of Łódź, Poland. Her academic interests revolve around modern drama, Irish studies, and cultural disability studies. She is the author of "Dancing as if language no longer existed": Dance in Contemporary Irish Drama (Reimagining Ireland 61, Peter Lang, 2015).

\section{k.ojrzynska@sens.net.pl}

